\title{
Preparation and application of unhairing enzyme using solid wastes from the leather industry - an attempt toward internalization of solid wastes within the leather industry
}

\author{
Renganath Rao Ramesh $^{1} \cdot$ Vimudha Muralidharan $^{1} \cdot$ Saravanan Palanivel $^{1}$ (D)
}

Received: 2 May 2017 / Accepted: 23 October 2017 /Published online: 6 November 2017

(C) Springer-Verlag GmbH Germany 2017

\begin{abstract}
Usage of the animal fleshing waste as the source of carbon and nitrogen for animal skin unhairing protease (EC 3.4.21) production along with agro-industrial wastes like wheat bran has been investigated. Thermal hydrolysis of delimed fleshing waste for $3 \mathrm{~h}$ yielded a fleshing hydrolysate (FH) having a protein content of $20.86 \mathrm{mg} / \mathrm{mL}$ and total solids of $46,600 \mathrm{ppm}$. The FH was lyophilized and spray dried to obtain fleshing hydrolysate powder (FHP) to be used along with wheat bran and rice bran for protease production. The carbon, nitrogen, hydrogen, and sulfur contents of the FHP were found to be $40.1,13.8,5.4$, and $0.2 \%$. The control solidstate fermented (SSF) medium without FHP showed a maximum activity of only $550 \mathrm{U} / \mathrm{g}$. A maximum protease activity of $956 \mathrm{U} / \mathrm{g}$ was obtained by using $6 \% \mathrm{FHP}$ (taken based on the combined total weight of wheat bran and rice bran) after $96 \mathrm{~h}$ of fermentation, resulting in a 1.7 -fold increase in the protease activity. The total cost of producing $1 \mathrm{~kg}$ of FHP and the cost of producing $1000 \mathrm{kU}$ of protease using FHP along with wheat bran and rice bran were found to be USD 24.62 and USD 2.08, respectively; $25 \%$ of SSF protease along with $40 \%$ water was found to be capable of unhairing the sheepskins in $7 \mathrm{~h}$ eliminating the hazardous conventional lime sulfide unhairing system. Thus, the leather industry's solid waste
\end{abstract}

Responsible editor: Gerald Thouand

Electronic supplementary material The online version of this article (https://doi.org/10.1007/s11356-017-0550-9) contains supplementary material, which is available to authorized users.

Saravanan Palanivel saravananclri@gmail.com

1 Leather Process Technology Department, Central Leather Research Institute, Adyar, Chennai 600 020, India internalized for the production of unhairing enzyme resulted in a sustainable solution for pollution problems.

Keywords Fleshing waste $\cdot$ Thermal hydrolysis · Fleshing hydrolysate $\cdot$ Solid-state fermentation $\cdot$ Protease unhairing kinetics $\cdot$ Pollution load

\section{Introduction}

Leather and leather products have been proven to be an inevitable element in various industries even at a time when synthetics are predominantly ruling. This is because of its versatile properties that beat over the synthetics. However, the leather making process generates wastes that make it fall in the "red" category (Fathima et al. 2012). Leather making process is compartmentalized into four stages viz. pretanning, tanning, posttanning, and finishing. Each of the stage contributes to water, land, and air pollution or all of it. Pretanning and tanning stages contribute to $80-90 \%$ of total pollution load (Saravanabhavan et al. 2005). Unhairing of animal skins/ hides is achieved by conventional chemical-based method called liming. Liming is a process, which decides the final quality of the leather. Nevertheless, such important process step has a major drawback of using sparingly water-soluble lime and environmentally harmful sodium sulfide. The continued action of $\mathrm{OH}$ and $\mathrm{SH}$ from the alkali and sulfide causes breakdown of disulfide bond in cysteine, resulting in disintegration of the structurally sound hair protein, keratin. Hair from the raw material is either pulped or removed intact. Pulping of hair increases the biochemical oxygen demand (BOD), chemical oxygen demand (COD), and TS of the 
wastewater (Kanagaraj et al. 2016). This process ends up in generating loads of hair wastes and lime sludge as solid wastes. In addition to this, the sulfide emission from the process creates air pollution. Many alternatives to liming have been researched since a long time (Kamini et al. 1999; Thanikaivelan et al. 2000). Several other chemical-based unhairing methods include the use of chlorine dioxide (Scroggie 1969), dimethyl sulfates (DMAS) (Frendrup 2000), hydrogen peroxide (Morera et al. 2016), and carbonates (Kanagaraj et al. 2016). Enzymes from a variety of origins have been tried and tested for the purpose of hair removal. Pancreatic proteases were used for unhairing of hides since 1910 (Rohm 1910), but pancreatic proteases have been replaced by microbial proteases. Among a large number of microbial enzymes, proteases occupy a pivotal position owing to its wide application. Proteases catalyze the breakdown of proteinaceous substrates. Proteases from microbial origin such as bacterial and fungal origins have been reported earlier. Thanikaivelan et al. (2005) reviewed the emerging novel enzymatic methods in leather processing. Dettmer et al. (2012) researched the application of protease from Bacillus subtilis aiming at the replacement of the chemical method of unhairing by complete enzyme-based method. Reports from CSIR-CLRI presented a system of unhairing using crude protease from Bacillus pumilus (MTCC 7514) (Saravanan et al. 2014), which was found to be effective in removing the hair completely. Alkaline protease with protease activity $100 \mathrm{U} /$ $\mathrm{mL}$ from Vibrio metschnikovii NG 155 was used for sulfide free enzymatic dehairing of skins and hides for $8 \mathrm{~h}$ resulting in better dyed crust leathers than chemically dehaired skins (George et al. 2014). Application of protease produced by solid-state fermentation (SSF) of Bacillus amyloliquefaciens in the unhairing of hides and skins resulted in an eco-friendly process for manufacturing good quality leathers from skins (George et al. 1995). Among mold/fungal proteases, proteases from Aspergillus flavus and A. terreus (Chellapandi 2010), Conidiobolus brefeldianus (Harish et al. 2015), A. oryzae, A. fumigatus, A. effusus, A. wentii, and A. parasiticus (Gillespie 1953) exhibited unhairing potency. Enzymes from Streptomyces sp. such as S. moderatus NRRL 3150 and S. froadiae (Chandrasekaran and Dhar 1983), Thermoactinomyces sp. RM4 (Arunachalam and Saritha 2009), S. griseus (Gehring 2002), and S. nogalator (Mitra and Chakrabartty 2005) were also found to be effectively unhairing the skins and hides. There has been an attempt on using enzymatic preparations consisting of protease enzymes, sodium hydroxide, sodium sulfide, and disodium hydrophosphate for sulfide-enzymatic unhairing of skins and hides (Valeika et al. 2009). Combination of bacterial enzyme from Bacillus subtilis BLBc 11 and hydrogen peroxide was also researched as a replacement of lime-sulfide-based unhairing (Andrioli et al. 2014). The exorbitant cost of enzyme production and stringent process control involved when using enzymes for unhairing deters the method to be commercially accepted (Saravanan et al. 2014). Thus, for developing a better enzymatic unhairing method, these two shortcomings need to be addressed.

Enzymes are produced through two different fermentation technologies viz. submerged fermentation $(\mathrm{SmF})$ and solidstate fermentation (SSF). SSF offers numerous advantages over submerged fermentation, which includes high volumetric productivity, relatively higher concentrations of the products, less effluent generation, and requirement of simpler fermentation equipment (Ashok et al. 1999). Also, the SSF method is preferable for the applications where the crude fermented product may be directly used as the enzyme source (Tengerdy 1998). This cuts down the cost involved in the downstream processing of enzyme unlike in SmF. SSF involves the use of low-cost easily available substrates that are wastes generated from other industries. Agro-industrial wastes such as rice bran, rice straw, cotton, bagasse, and wheat bran have been studied for the induction and biosynthesis of protease (Muthulakshmi et al. 2011). Several synthetic co-carbon and co-nitrogen sources were researched for better induction of protease in SSF (Rajkumar et al. 2011). Utilization of fish wastes for production of protease for the application of unhairing was also done (Saranya et al. 2016). The leather industry generates a tremendous amount of solid wastes that are majorly proteinaceous in nature. These wastes are disposed of by several conventional techniques such as incineration, landfilling, gasification, and dumping. Here, the difference between the landfilling and dumping is that in landfill technique the bottom of the pit has a liner, which prevents the leaching of toxins or other pollutants into the soil and contaminating the water resources. This liner is not found in dump yards. Though the solid waste disposal technologies are available and efficient for ecological production, the improvements are continuously required. Hide fleshings from pretanning processes accounts for $50-60 \%$ of waste generated in the tannery. The bovine hide fleshing has been reported to contain $80 \%$ water, $63 \%$ protein content (on dry basis), $14 \%$ fat, and $8 \%$ ash content (Dayanandan et al. 2013). Recently, studies have been conducted for the production of unhairing protease using another class of tannery solid waste - chrome shavings-leading to a cleaner leather production (Shakilanishi et al. 2017). Reutilization of tannery fleshings for poultry and fish feed (Jini et al. 2016) and biofuel production (Colak et al. 2005; Vasudevan and Ravindran 2007) has been researched so far. The animal fleshing (ANFL) was also bacterially composted for a period of 49 days to suit the physical, physicochemical, and other parameters necessary for it to be used as organic manure (Ravindran and Sekaran 2010). The untanned skin wastes were thermally and enzymatically hydrolyzed to prepare protein hydrolysate of satisfactory protein concentrations (Bajza and Vrcek 2001). The fat obtained from fleshing wastes has been reutilized for the manufacture of 
fatliquor for leather making purpose (Santos and Gutterres 2007). The fleshing hydrolysate, on the other hand, has been used as retanning agents for leather (Castiello et al. 2006). The fleshing hydrolysate could be a better inducer to be used along with the agro-wastes for increased protease production.

The present work dealt with the production of unhairing protease (serine protease-EC 3.4.21) using actinomycete Brevibacterium luteolum (MTCC 5982) on low-cost agro-industrial wastes along with animal fleshing hydrolysate for the unhairing application. The use of agro-wastes enriched with fleshing hydrolysate paved a way for better reutilization and recycling of the leather industry's solid waste.

\section{Materials and methods}

\section{Chemicals and raw materials}

All chemicals used for this work were of analytical grade obtained from M/s Sigma Aldrich and M/s Himedia. Wet salted goatskins and sheepskins were obtained from a local slaughterhouse at Chennai, Tamil Nadu, India. Fleshing wastes containing the flesh layer of cow, buffalo, goat, and sheep were obtained from the Lime yard of Leather Process Technology Department of Central Leather Research Institute, Chennai, Tamil Nadu, India.

\section{Preparation of fleshing hydrolysate from animal fleshing waste}

The fleshing wastes collected were a mixture of flesh layer of goat, sheep, buffalo, and cow. Fleshing waste is generally categorized as green fleshing waste and limed fleshing waste depending upon the process after which the fleshing is done. The green fleshing method where the fleshing is removed after the soaking process (prior to liming operation) is followed only in the case of hides such as cows and buffalos and not for skins such as goat and sheep. This is because of low thickness of skins compared to that of hides leading to damage of skins when green fleshing is done. Thus, for skins, fleshing is mainly done after the liming process. Globally, a majority of the tanneries practice fleshing only after liming. Therefore, the limed fleshing wastes were used in the present research. However, for the fleshing wastes generated from green fleshing, the deliming operation need not be done. The fleshing wastes from varied species were taken for the current research so as to make the method of reutilizing fleshing wastes widespread and facile. The method of separating, characterizing fleshing wastes from each of the species, and then using it for the research purpose would make it cumbersome and less approachable when reutilization of tannery wastes at industrial scale is considered. Initially, the fleshing wastes were washed with $300 \% \mathrm{w} / \mathrm{w}$ water in a drum to remove the lime that was physically adhered on the surface of the fleshing waste. Deliming using ammonium chloride salt was carried out to completely remove the lime that is chemically adhered to the fleshing waste. The wash liquor was drained out and $100 \% \mathrm{w} /$ $w$ freshwater was added along with $3 \% w / w$ ammonium chloride in a drum. This was run at $12 \mathrm{rpm}$ for around $2 \mathrm{~h}$. The complete removal of lime was ensured using phenolphthalein indicator. The completion of the lime removal was indicated by the colorless indication in the liquor by the phenolphthalein indicator. The fleshing wastes were again washed thoroughly with $300 \% \mathrm{w} / \mathrm{w}$ water and subjected to thermal hydrolysis. All the $w / w$ calculations were based on the weight of the fleshing waste taken.

\section{Thermal hydrolysis of fleshing wastes}

Lime-free fleshing wastes were then thermally hydrolyzed in an autoclave at $121^{\circ} \mathrm{C}$ at a pressure of $15 \mathrm{psi}$ for $5 \mathrm{~h}$. To $2.5 \mathrm{~kg}$ of fleshing waste taken in a 5-L beaker, $1 \mathrm{~L}$ of tap water was added to completely immerse the fleshing waste in water and the thermal hydrolysis was carried out in an autoclave. The hydrolysis process was conducted in triplicates and the average value of the weight of fleshing waste remaining was noted down. The hydrolyzed fleshing wastes were then cooled down overnight at room temperature (or at $4{ }^{\circ} \mathrm{C}$ for $3 \mathrm{~h}$ ) and centrifuged the next day to separate the fleshing hydrolysate (FH) and the lipid part. FH was then lyophilized and spray dried to obtain fleshing hydrolysate powder (FHP) and stored at $4{ }^{\circ} \mathrm{C}$.

The extent of hydrolysis at different hydrolysis intervals was estimated by finding the difference in weight of the initial fleshing wastes taken and the remaining fleshing waste present in the unhydrolyzed form after the hydrolysis reaction as in Eq. 1.

\section{$\%$ Extent of Hydrolysis

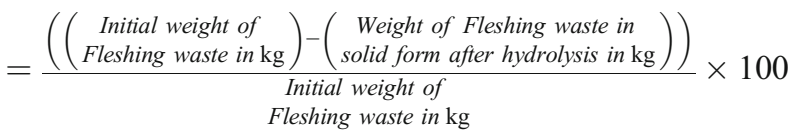

Also, the effect of hydrolysis was ascertained by measuring the nitrogen content of the fleshing hydrolysate samples at different hydrolysis durations, which were then compared with the initial nitrogen content of the fleshing waste taken for the hydrolysis process. For the estimation of nitrogen content, the same procedure explained in the subsection "Elemental analysis of FHP" was followed.

\section{Elemental analysis of FHP}

Carbon, hydrogen, nitrogen, and sulfur contents of the FHP were determined to find out whether the abovementioned 
media components could be a better replacement for the other synthetic media components such as yeast extract available in the market. Three to $5 \mathrm{mg}$ of FHP was packed in a silver capsule and fed into the combustion zone of the elemental analyzer (Vario Micro Cube, Elementar, Japan) and the corresponding results were recorded.

\section{Determination of protein content}

The protein content of the cell-free supernatant was determined using Lowry's protein estimation (Lowry et al. 1951). To $0.2 \mathrm{~mL}$ of sample, $2 \mathrm{~mL}$ of alkaline copper sulfate reagent (analytical reagent) was added. The contents of the test tube were mixed well by inversion. This solution was incubated at room temperature for $10 \mathrm{~min}$. Then, $0.2 \mathrm{~mL}$ of FolinCiocalteau solution was added to each tube and incubated for $30 \mathrm{~min}$. The UV-Vis spectrophotometer (Jasco V-660) was zeroed with a blank and the optical density (absorbance) of the solution was measured at $660 \mathrm{~nm}$. The absorbance was recorded and the concentration of the unknown sample was found out. Bovine serum albumin (BSA) of concentration ranging from 0.05 to $1 \mathrm{mg} / \mathrm{mL}$ was used as the protein standard.

\section{Analysis of total solids}

The total solids content was analyzed as mentioned in IS: 3025 (part-15): 1984 (1st revision) (reaffirmed-2003) (BIS 2003).

\section{Determination of protease activity}

Casein-based protease assay was followed to determine the protease activity (Cupp-Enyard 2008). To $5 \mathrm{~mL}$ of $0.65 \%$ casein solution preincubated at $37{ }^{\circ} \mathrm{C}$ for $5 \mathrm{~min}$, $1 \mathrm{~mL}$ of the enzyme was added and incubated at $37^{\circ} \mathrm{C}$ for $10 \mathrm{~min}$. The reaction was terminated by adding $5 \mathrm{~mL}$ of $110 \mathrm{mM}$ trichloroacteic acid (TCA) solution and filtered after incubating the solution for $30 \mathrm{~min}$ at $37{ }^{\circ} \mathrm{C}$. For the blank, $1 \mathrm{~mL}$ of the enzyme was added after the addition of TCA solution. To $2 \mathrm{~mL}$ of the filtrate, $5 \mathrm{~mL}$ of $500 \mathrm{mM}$ sodium carbonate solution was added along with $1 \mathrm{~mL}$ of Folin's reagent and incubated at $37{ }^{\circ} \mathrm{C}$ for $30 \mathrm{~min}$. The absorbance of the sample was measured at $660 \mathrm{~nm}$ using a spectrophotometer. Tyrosine solution of concentration 10 to $100 \mu \mathrm{g}$ was used as the standard. One unit of protease enzyme activity was defined as the amount of enzyme required to liberate $1 \mu \mathrm{g}$ of tyrosine under standard assay conditions. The activity obtained was divided by bran concentration (i.e., for $1 \mathrm{~g}$ bran in $10 \mathrm{~mL}$ of water; concentration $=0.1 \mathrm{~g} / \mathrm{mL}$ ) to convert the activity into units per gram of fermented substrate.

\section{Production of SSF enzyme}

Brevibacterium luteolum (MTCC 5982), a protease producing actinomycete, previously isolated in the laboratory was used for this study. To $50 \mathrm{~g}$ of bran (wheat bran $=37.5 \mathrm{~g}$; rice bran $=12.5 \mathrm{~g})$ in $1 \mathrm{~L}$ Erlenmeyer flasks, $130 \%(w / w)$ tap water was added as the moistening agent (Renganath et al. 2017). FHP in varied concentration was used as the additional source of carbon and nitrogen for enzyme production. To this mixture maintained at $\mathrm{pH} 9.0,15 \%$ of preinoculum prepared using nutrient broth was added and incubated for $96 \mathrm{~h}$ at $33{ }^{\circ} \mathrm{C}$. The SSF medium was manually stirred once for $24 \mathrm{~h}$ using a sterile glass rod to ensure proper supply of oxygen for the growth of the microorganism. The enzyme was extracted after $96 \mathrm{~h}$ using Tris buffer ( $\mathrm{pH}$ 7.4). To $1 \mathrm{~g}$ of fermented bran, $10 \mathrm{~mL}$ of Tris buffer was added and kept at $150 \mathrm{rpm}$ in a shaker for $3 \mathrm{~h}$. It was then centrifuged at $10,000 \mathrm{rpm}$ at $4{ }^{\circ} \mathrm{C}$ for $10 \mathrm{~min}$ to remove the solid bran and cells. The supernatant was then used for further analysis. Bulk production of SSF enzyme was carried out in plastic trays that were sterilized by wiping completely with ethanol followed by UV irradiation for $15 \mathrm{~min}$.

\section{Proteoglycan and glycosaminoglycan analysis}

Periodic acid of volume $10 \mu \mathrm{L}$ of $50 \%$ strength was mixed with $10 \mathrm{~mL}$ of $7 \%$ acetic acid. Standards ranging from 0 to $100 \mu \mathrm{g}$ of mucin (glycoprotein) were added to $1 \mathrm{~mL}$ of water followed by the addition of $100 \mu \mathrm{L}$ of freshly prepared periodic acid solution. The contents of the reaction mixture were mixed well and incubated at $37^{\circ} \mathrm{C}$ for $120 \mathrm{~min}$. For full color development, $100 \mu \mathrm{L}$ of decolorized Schiff's reagent was added to each of the standards, mixed, and allowed to remain at room temperature for $30 \mathrm{~min}$. Water was used as the blank. For analyzing proteoglycan (PG) levels in spent liquor samples from all the unhairing trials, the sample volume of $0.1 \mathrm{~mL}$ was taken and made up to $1 \mathrm{~mL}$ and the other reagents were added accordingly. The absorbance of each sample was measured at $555 \mathrm{~nm}$ (Mantle and Allen 1978).

For analyzing the glycosaminoglycan (GAG) concentrations in the sample, a direct spectrophotometric method using dimethylene blue was followed (Farndale et al. 1982). Dimethylmethylene blue (DMB) solution was prepared by adding DMB $(16 \mathrm{mg})$ in $5 \mathrm{~mL}$ ethanol, and sodium formate $(2 \mathrm{~g})$ and formic acid $(2 \mathrm{~mL})$ were added and stirred well. This solution was made up to $1 \mathrm{~L}$ with distilled water and was used for the assay. To $0.25 \mathrm{~mL}$ of the sample solution, $2.5 \mathrm{~mL}$ of DMB solution was added and the absorbance was immediately measured at $535 \mathrm{~nm}$. The standard curve was plotted by using standard solutions of chondroitin-4-sulfate (M/s Sigma) concentrations ranging from 20 to $80 \mu \mathrm{g} / \mathrm{mL}$ with a suitable blank. 


\section{Biochemical oxygen demand of the spent liquors}

BOD of an effluent is the milligram of oxygen required to biologically stabilize $1 \mathrm{~L}$ of that effluent (by biodegradation of organic compounds with the help of microorganisms) in 5 days at a temperature of $20^{\circ} \mathrm{C}$. BOD, one of the pollution parameters, was analyzed following the standard procedure as reported by the American Public Health Association (APHA 1989).

\section{Chemical oxygen demand of the spent liquors}

The chemical oxygen demand of an effluent means the quantity of oxygen, in milligrams, required to oxidize or stabilize the oxidizable chemicals present in $1 \mathrm{~L}$ of effluent under the specific condition. COD, one of the pollution parameters, was analyzed following the standard procedure as reported by the American Public Health Association (APHA 1989).

\section{Determination of collagen content released in spent liquor}

The extent of collagen degradation in the skin by the unhairing enzyme was determined by measuring the hydroxyproline content, a key amino acid released during the breakdown of the collagen. Skin sample before unhairing was collected, washed with physiological saline, and cut into small pieces weighing about $1 \mathrm{~g}$. Skin piece was hydrolyzed with $5 \mathrm{~mL}$ of $6 \mathrm{~N}$ hydrochloric acid at $110{ }^{\circ} \mathrm{C}$ for overnight in sealed test tubes. After hydrolysis, the samples were evaporated to dryness, and the residue was dissolved in water and made up to $5 \mathrm{~mL}$ and used for hydroxyproline determination. Hydroxyproline oxidation was initiated by adding $1 \mathrm{~mL}$ of chloramine-T to each test tube. The contents of the tubes were mixed by shaking for a few minutes and allowed to stand for $20 \mathrm{~min}$ at room temperature; $1 \mathrm{~mL}$ of perchloric acid was added to each test tube and the contents were mixed and allowed to stand for $5 \mathrm{~min}$. Finally, $1 \mathrm{~mL}$ of para-dimethylaminobenzaldehyde (PDAB) solution was added and the mixture was mixed well. The tubes were placed in a $60{ }^{\circ} \mathrm{C}$ water bath for $20 \mathrm{~min}$ and then cooled down in tap water for $5 \mathrm{~min}$. The spent liquor from the enzymatically unhaired skin sample was collected and $1 \mathrm{~mL}$ of it was made up to $5 \mathrm{~mL}$ with water. The rest of the determination procedure was followed as mentioned before. The color developed was measured at $557 \mathrm{~nm}$ and the concentration of hydroxyproline was calculated using hydroxyproline standard ranging from 1 to $10 \mu \mathrm{g} / \mathrm{mL}$. Collagen content is 7.46 times of the amount of hydroxyproline (Woessner 1961).

\section{Physical testing of leather}

The testing methods were followed based on the IUP as prescribed in IULTCS Official Methods of Analysis for Leather (updated version October 2015), which is applicable for physical testing of leather worldwide. Sampling for physical testing of leather was done appropriately (IUP 2 2000). The leathers from the enzymatically unhaired pelts were tested for physical properties such as tensile strength, tear strength, grain cracking, and grain bursting using standard procedures (IUP 6 2000; IUP 8 2000; IUP 12 2000; IUP 9 2000). The obtained results were compared with the physical characteristics for leathers as prescribed by the UNIDO (UNIDO 1996).

\section{Results and discussion}

\section{Thermal hydrolysis of animal fleshing waste and the effect of hydrolysis time on the extent of hydrolysis}

The thermal hydrolysis was carried out for 1 up to $5 \mathrm{~h}$ and its effect on the extent of hydrolysis on fleshing waste was observed. Initially, the hydrolysis was quicker for the first $2 \mathrm{~h}$ with the extent of hydrolysis reaching up to 55\% for the first hour and $78 \%$ for the second. The hydrolysis process reached a saturation level at $90 \%$ after $3 \mathrm{~h}$. Thus, the optimal thermal hydrolysis time was recorded as $3 \mathrm{~h}$ (Table 1). Also, the hydrolysis was ascertained by measuring the nitrogen content of the fleshing hydrolysate obtained. A maximum nitrogen content of $13.75 \pm 0.27 \% \mathrm{w} / \mathrm{w}$ was obtained (in the hydrolysate form) out of the fleshing waste containing $15.52 \pm 0.31 \% \mathrm{w} / \mathrm{w}$ nitrogen content after $3 \mathrm{~h}$ of hydrolysis.

\section{Properties of the FH and FHP}

The hydrolyzed fleshing waste was cooled down overnight at room temperature for the complete separation of the lipid part and the FH. The lipid part was clearly observed on the top as a separate layer (Fig. 1). This layer was skimmed off using a spatula and the remaining solution was filtered using a muslin cloth to separate the bigger lipid particles. Further, the lipid particles were removed by centrifuging at $4{ }^{\circ} \mathrm{C}$ for $15 \mathrm{~min}$ at $10,000 \mathrm{rpm}$. This lipid-free supernatant was first lyophilized to increase the

Table 1 Effect of hydrolysis time on the extent of hydrolysis

\begin{tabular}{lllll}
\hline $\begin{array}{l}\text { Thermal } \\
\text { hydrolysis } \\
\text { time (h) }\end{array}$ & $\begin{array}{l}\text { Initial weight } \\
\text { of the } \\
\text { fleshing } \\
\text { waste }(\mathrm{kg})\end{array}$ & $\begin{array}{l}\text { Weight of } \\
\text { fleshing waste } \\
\text { after hydrolysis } \\
(\mathrm{kg})\end{array}$ & $\begin{array}{l}\text { Extent of } \\
\text { hydrolysis } \\
(\%)\end{array}$ & $\begin{array}{l}\% \text { nitrogen } \\
\text { present in the } \\
\text { hydrolysate }\end{array}$ \\
\hline 0 & 2.5 & - & - & $15.52 \pm 0.31$ \\
1 & 2.5 & $1.124 \pm 0.011$ & 55 & $8.14 \pm 0.12$ \\
2 & 2.5 & $0.570 \pm 0.010$ & 78 & $12.13 \pm 0.35$ \\
3 & 2.5 & $0.250 \pm 0.013$ & 90 & $13.75 \pm 0.27$ \\
4 & 2.5 & $0.223 \pm 0.005$ & 91 & $13.77 \pm 0.18$ \\
5 & 2.5 & $0.225 \pm 0.003$ & 91 & $13.78 \pm 0.24$ \\
\hline
\end{tabular}


a

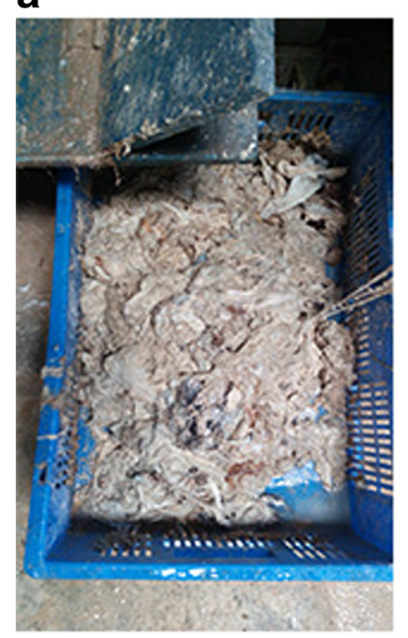

b

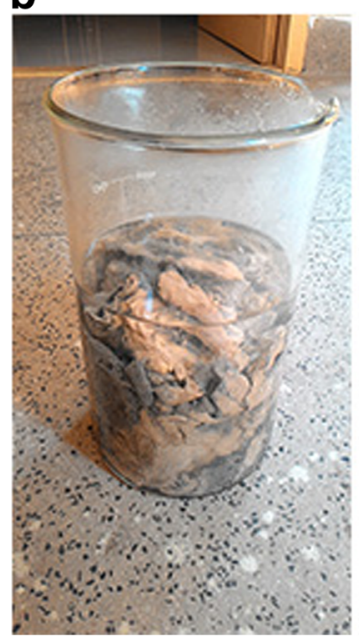

C

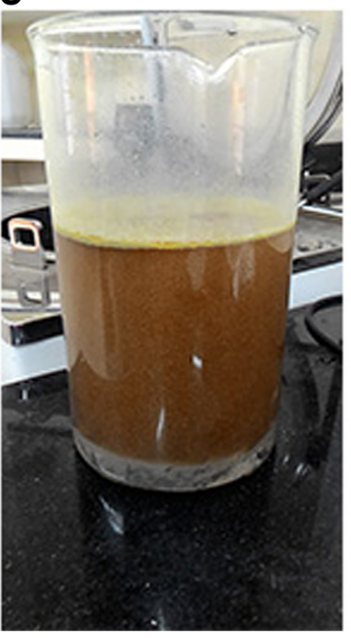

d

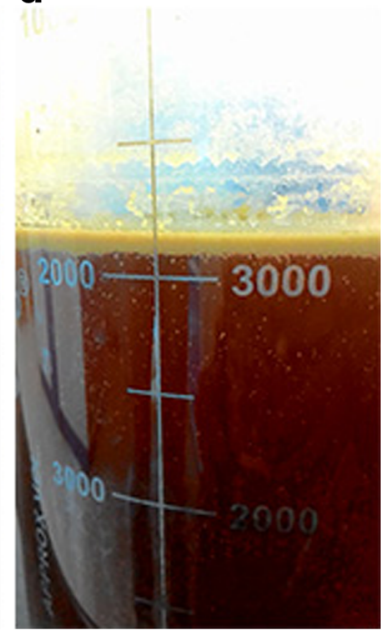

Fig. 1 a Collection of limed animal fleshing waste from the fleshing machine. b Fleshing waste after preprocessing. c Fleshing waste after thermal hydrolysis. d Fleshing lipid and FH as separate layers

total solid content up to $20 \%$ and then spray dried to obtain FHP. The protein content and the total solids content of the lipid-free supernatant $(\mathrm{FH})$ were found to be $20.86 \pm 1.52 \mathrm{mg} / \mathrm{mL}$ and $46,600 \pm 500$ ppm (i.e., around 5\% total solid content). The carbon, nitrogen, hydrogen, and sulfur contents of the FHP were found to be $40.1 \pm 0.4,13.8 \pm 0.2,5.4 \pm 0.1$, and $0.2 \pm 0.03 \%$, respectively. This showed that the FHP from the animal fleshing waste could be a better source of carbon and nitrogen for the growth of microorganism under SSF for the production of secondary metabolites.

\section{Production of SSF protease using protein hydrolysate from fleshing waste}

Keeping all the process conditions constant, the FHP was added in varying concentrations from 2 to $10 \%$ with an incrementing order of 2 units. The concentration of FHP was calculated based

Table 2 Standardization of FHP concentration for SSF protease production

\begin{tabular}{lllll}
\hline Bran & & FHP (g) & $\begin{array}{l}\text { Concentration of FHP in } \\
\text { fermentation medium }(\%)\end{array}$ & $\begin{array}{l}\text { Protease } \\
\text { activity } \\
(\mathrm{U} / \mathrm{g})\end{array}$ \\
\cline { 1 - 2 } $\begin{array}{l}\text { Wheat } \\
\text { bran }(\mathrm{g})\end{array}$ & $\begin{array}{l}\text { Rice } \\
\text { bran } \\
(\mathrm{g})\end{array}$ & & & $703 \pm 10$ \\
\hline 37.5 & 12.5 & 1 & 2 & $860 \pm 13$ \\
37.5 & 12.5 & 2 & 4 & $956 \pm 11$ \\
37.5 & 12.5 & 3 & 6 & $957 \pm 10$ \\
37.5 & 12.5 & 4 & 8 & $938 \pm 12$ \\
37.5 & 12.5 & 5 & 10 & $550 \pm 11$ \\
37.5 & 12.5 & 0 & 0 & \\
& \multicolumn{5}{c}{ (con- } \\
\end{tabular}

on the weight of wheat bran. The maximum protease activity of $956 \mathrm{U} / \mathrm{g}$ was obtained with $6 \%$ FHP along with wheat bran and rice bran (Table 2). The activity of the protease enzyme produced by the microorganism reaches a maximum level at concentrations more than $6 \% w / w$ FHP in the fermentation medium. This may be due to that fact that the maximum nutrient required for microbial growth was made available with $6 \% w / w$ FHP. At higher FHP concentration, the increased nitrogen content of the fermentation medium may cause nitrogen toxicity and could be detrimental to the microbial growth. Similar results showing a decrease in protease activity of the enzyme obtained after a certain amount of media component concentration were reported by Mabrouk et al. (1999) and Patel et al. (2006). The control SSF medium with no FHP showed a maximum activity of $550 \mathrm{U} / \mathrm{g}$. There was a 1.7 -fold increase in the protease activity obtained. This proved that the FHP from the animal fleshing waste acted as a very good source of carbon and nitrogen for protease production. The final media composition for production of SSF protease using FHP is tabulated in Table 3. The obtained

Table 3 SSF media composition for production of protease enzyme using FHP

\begin{tabular}{ll}
\hline Media composition & Quantity required for 1 kg enzyme production \\
Wheat bran & $750 \mathrm{~g}$ \\
Rice bran & $250 \mathrm{~g}$ \\
FHP & $60 \mathrm{~g}$ \\
Water & $1300 \mathrm{~mL}$ \\
Inoculum & $150 \mathrm{~mL}$ \\
Physiological conditions & \\
pH & 9.0 \\
Temperature & $33{ }^{\circ} \mathrm{C}$ \\
Fermentation time & $96 \mathrm{~h}$
\end{tabular}


Table 4 Cost of production of $1 \mathrm{~kg}$ of FHP on a lab-scale level

\begin{tabular}{|c|c|c|c|c|c|}
\hline Steps & $\begin{array}{l}\text { Raw materials/ } \\
\text { equipment }\end{array}$ & $\begin{array}{l}\text { Power } \\
\text { consumption }\end{array}$ & $\begin{array}{l}\text { Cost of raw material/cost of } \\
\text { power consumption }\end{array}$ & $\begin{array}{l}\text { Quantity of raw material required } \\
\text { for } 1.25 \mathrm{~kg} \text { FHP production }\end{array}$ & $\begin{array}{l}\text { Cost of raw material required for } \\
1.25 \mathrm{~kg} \text { FHP production }\end{array}$ \\
\hline \multirow{4}{*}{$\begin{array}{l}\text { Preprocessing of } \\
\text { fleshing waste }\end{array}$} & Fleshing waste & - & - & $25 \mathrm{~kg}$ & - \\
\hline & Tap water & - & USD $0.22 / 1000 \mathrm{~L}$ & $75 \mathrm{~L}$ & Very negligible \\
\hline & $\begin{array}{l}\text { Ammonium } \\
\text { chloride }\end{array}$ & - & USD $120 / \mathrm{t}$ & $1 \mathrm{~kg}$ & 0.12 \\
\hline & Drum & $4.5 \mathrm{kWh}$ & USD $0.09 / \mathrm{kWh}$ & - & 0.41 \\
\hline \multirow[t]{5}{*}{ FHP production } & Tap water & - & USD $0.22 / 1000 \mathrm{~L}$ & $10 \mathrm{~L}$ & Very negligible \\
\hline & $\begin{array}{l}\text { Preprocessed } \\
\text { fleshing } \\
\text { waste }\end{array}$ & - & - & $25 \mathrm{~kg}$ & - \\
\hline & $\begin{array}{l}\text { Thermal } \\
\text { hydrolysis }\end{array}$ & $12 \mathrm{kWh}$ & USD $0.09 / \mathrm{kWh}$ & - & 1.08 \\
\hline & Lyophilization & $288 \mathrm{kWh}$ & USD $0.09 / \mathrm{kWh}$ & - & 25.92 \\
\hline & Spray drying & $36 \mathrm{kWh}$ & USD $0.09 / \mathrm{kWh}$ & - & 3.24 \\
\hline \multicolumn{5}{|c|}{ Total cost for producing $1.25 \mathrm{~kg} \mathrm{FHP}$} & USD 30.77 \\
\hline \multicolumn{5}{|c|}{ Total cost for producing $1 \mathrm{~kg} \mathrm{FHP}$} & USD 24.62 \\
\hline
\end{tabular}

enzyme was shade dried to reduce the moisture content to $5 \%$ and stored at a dry cool place until further usage.

\section{Cost of production of FHP and comparison with commercial media components}

The cost involved in the production of FHP from the animal fleshing wastes was calculated by taking into account the cost of chemicals and the cost of services like electricity consumption incurred during the production process. It was found that from $2.5 \mathrm{~kg}$ of fleshing waste, $2.8 \mathrm{~L}$ of $\mathrm{FH}$ was produced which accounts to a total solid content of about $130.5 \mathrm{~g}$. Experimentally, around $125 \mathrm{~g}$ of FHP was obtained from $2.5 \mathrm{~kg}$ of fleshing waste. Based on these results, a total of $25 \mathrm{~kg}$ of fleshing waste was taken for the production of $1.25 \mathrm{~kg}$ of FHP. It was found that a total cost of USD 24.62 (Table 4) was required to produce $1 \mathrm{~kg}$ of the FHP excluding the taxes and other services like labor charges, etc. This cost could be further reduced when the production is carried out on an industrial scale. From Table 5, on comparing the cost of FHP with other media components, it can be concluded that FHP can be a cheaper alternative to commercially available media components as well as address the issue of solid waste generation from the leather industry. The value of 1 USD equals to 60 INR throughout the study.

\section{Comparison of cost of production of protease enzyme using FHP and other commercial media components}

The cost involved in the production of $1000 \mathrm{kU}$ protease units under SSF using wheat bran along with FHP and other media components was also calculated to demonstrate the economic viability of the process. The media components such as yeast extract, casein hydrolysate, starch, and protease peptone were used for the protease production along with the wheat bran and rice bran (Table 6). The protease activity obtained using the commercial media components was experimentally identified by replacing FHP in the fermentation process with the abovementioned commercial media components. It was found that the cost of production of $1000 \mathrm{kU}$ of protease units was USD 2.08 (FHP), USD 2.76 (yeast extract), USD 4.05 (casein hydrolysate), USD 11.52 (protease peptone), and USD 4.61 ( starch), respectively (Table 7). This proved that FHP could be a better replacement for the commercial media components in the production of protease and also in the production of any biochemical component.

Table 5 Comparison of cost of FHP with commercial media components

\begin{tabular}{llll}
\hline $\begin{array}{l}\text { S. } \\
\text { no. }\end{array}$ & $\begin{array}{l}\text { Media } \\
\text { component }\end{array}$ & $\begin{array}{l}\text { Cost of 1 kg media component* } \\
\text { (USD) }\end{array}$ & $\begin{array}{l}\text { Sigma } \\
\text { product ID }\end{array}$ \\
\hline 1 & FHP & 24.62 & - \\
2 & Yeast extract & 62.8 & 09182 \\
3 & $\begin{array}{c}\text { Casein } \\
\text { hydrolysate }\end{array}$ & 112.8 & 22,090 \\
4 & $\begin{array}{c}\text { Protease } \\
\text { peptone }\end{array}$ & 250.5 & $\mathrm{P} 0431$ \\
5 & $\begin{array}{c}\text { Starch } \\
\text { Ttar }\end{array}$ & 98.8 & $\mathrm{~S} 9765$ \\
\hline
\end{tabular}

* Costs of the media components were obtained from the online store of M/s Sigma-Aldrich chemicals 
Table 6 Cost of production of $5 \mathrm{~kg}$ unhairing protease enzyme using FHP and commercial media components

\begin{tabular}{|c|c|c|c|c|c|}
\hline Steps & $\begin{array}{l}\text { Raw } \\
\text { materials/ } \\
\text { equipment }\end{array}$ & $\begin{array}{l}\text { Power } \\
\text { consumption }\end{array}$ & $\begin{array}{l}\text { Cost of raw material/cost of } \\
\text { power consumption }\end{array}$ & $\begin{array}{l}\text { Quantity of raw material required } \\
\text { for } 5 \mathrm{~kg} \text { enzyme production }\end{array}$ & $\begin{array}{l}\text { Cost of raw material required for } 5 \mathrm{~kg} \\
\text { enzyme production (USD) }\end{array}$ \\
\hline \multirow{4}{*}{$\begin{array}{l}\text { Preinoculum } \\
\text { preparation }\end{array}$} & Nutrient broth & - & USD $74.72 / \mathrm{kg}$ & $0.01 \mathrm{~kg}$ & 0.75 \\
\hline & Distilled water & - & USD $0.03 / \mathrm{L}$ & $0.75 \mathrm{~L}$ & 0.02 \\
\hline & $\begin{array}{l}\text { Media } \\
\text { sterilization }\end{array}$ & $3 \mathrm{kWh}$ & USD $0.09 / \mathrm{kWh}$ & - & 0.27 \\
\hline & $\begin{array}{l}\text { Incubator } \\
\text { shaker }\end{array}$ & $3 \mathrm{kWh}$ & USD $0.09 / \mathrm{kWh}$ & - & 0.27 \\
\hline \multirow{9}{*}{$\begin{array}{l}\text { SSF enzyme } \\
\text { production }\end{array}$} & Wheat bran & - & USD $0.16 / \mathrm{kg}$ & $3.75 \mathrm{~kg}$ & 0.60 \\
\hline & Rice bran & - & USD $0.19 / \mathrm{kg}$ & $1.25 \mathrm{~kg}$ & 0.24 \\
\hline & FHP & - & USD $24.62 / \mathrm{kg}$ & $0.3 \mathrm{~kg}$ & 7.38 \\
\hline & Yeast extract & & USD $62.8 / \mathrm{kg}$ & & 18.84 \\
\hline & Casein & & USD $112.8 / \mathrm{kg}$ & & 33.84 \\
\hline & $\begin{array}{l}\text { Protease } \\
\text { peptone }\end{array}$ & & USD $250.5 / \mathrm{kg}$ & & 75.15 \\
\hline & Starch & & USD 98.8/kg & & 29.64 \\
\hline & Tap water & - & USD $0.22 / 1000 \mathrm{~L}$ & $6.5 \mathrm{~L}$ & Very negligible \\
\hline & Incubator & $4.8 \mathrm{kWh}$ & USD $0.09 / \mathrm{kWh}$ & - & 0.43 \\
\hline \multirow{5}{*}{\multicolumn{5}{|c|}{ Total cost for producing $5 \mathrm{~kg}$ unhairing enzyme }} & USD 9.96 \\
\hline & & & & & USD 21.42 \\
\hline & & & & & USD 36.42 \\
\hline & & & & & USD 77.73 \\
\hline & & & & & USD 32.22 \\
\hline
\end{tabular}

\section{Application of SSF enzyme for unhairing of animal skins}

\section{Standardization of pasting-based unhairing of sheepskins using concentrated enzyme}

The enzyme offer level was varied from 1 to $7 \% w / w$ with an increment of $2 \%$ and the hide-float ratio of 5 to $15 \% w / w$ with water with an increment of $5 \%$. All the $w / w$ calculations were made based on the soaked weight of the sheepskins. For pasting-based application of unhairing, the protease enzyme was extracted in Tris buffer ( $\mathrm{pH}$ 7.4) from the fermented bran and concentrated by lyophilization and adjusted to an activity of about $300 \mathrm{U} / \mathrm{mL}$ prior to application, which is referred to as concentrated liquid enzyme. The enzyme activity was measured at $\mathrm{pH}$ ranging from 5.0 to $11.0 \mathrm{in}$ an increasing order of 1.0 , and it was found that the maximum enzyme activity was observed at pH 9.0 (Fig. 2). Thus, the process of unhairing

Table 7 Cost of production of protease enzyme of $1000 \mathrm{kU}$ using FHP and commercial media components

\begin{tabular}{llllll}
\hline & FHP & $\begin{array}{l}\text { Yeast } \\
\text { extract }\end{array}$ & $\begin{array}{l}\text { Casein } \\
\text { hydrolysate }\end{array}$ & $\begin{array}{l}\text { Protease } \\
\text { peptone }\end{array}$ & Starch \\
\hline $\begin{array}{c}\text { Concentration of media } \\
\text { components in SSF }\end{array}$ & 6 & 6 & 6 & 6 & 6 \\
$\quad \begin{array}{l}\text { medium (\%) } \\
\text { Protease activity (U/g) }\end{array}$ & 960 & 1550 & 1800 & 1350 & 1400 \\
$\begin{array}{c}\text { Total protease units } \\
\text { obtained from 5 kg } \\
\text { enzyme (kU) }\end{array}$ & 4800 & 7750 & 9000 & 6750 & 7000 \\
$\begin{array}{c}\text { Cost of producing 5 kg } \\
\text { enzyme (USD) }\end{array}$ & 9.96 & 21.42 & 36.42 & 77.73 & 32.22 \\
$\begin{array}{c}\text { Cost of producing } \\
\quad \text { 1000 kU of protease } \\
\text { units (USD) }\end{array}$ & 2.08 & 2.76 & 4.05 & 11.52 & 4.61 \\
& & & & & \\
\end{tabular}

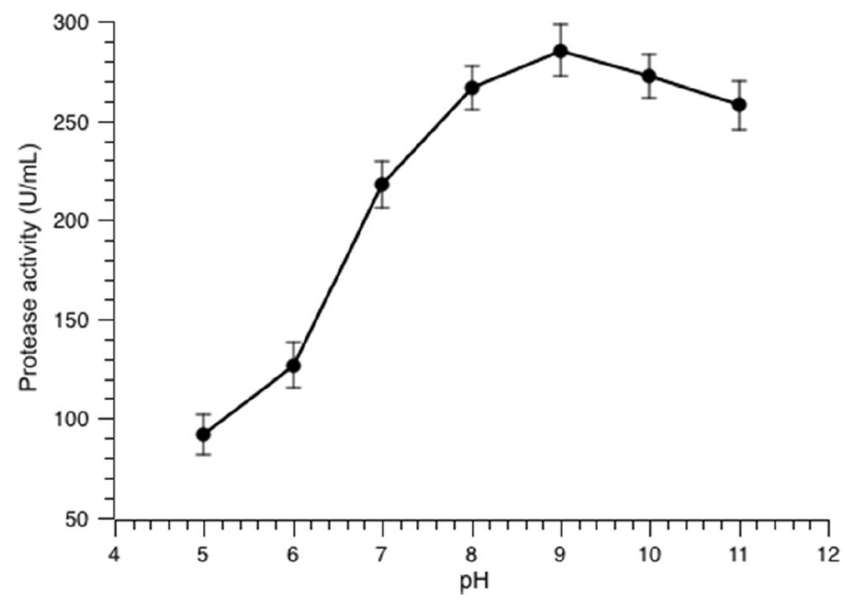

Fig. 2 Protease activity of the enzyme at various $\mathrm{pH}$ values 
Fig. 3 Unhairing application using SSF protease (concentrated liquid enzyme): a soaked sheepskin, b unhairing enzyme manually applied as paste on flesh side, and $\mathbf{c}$ unhaired sheepskin after $6 \mathrm{~h}$

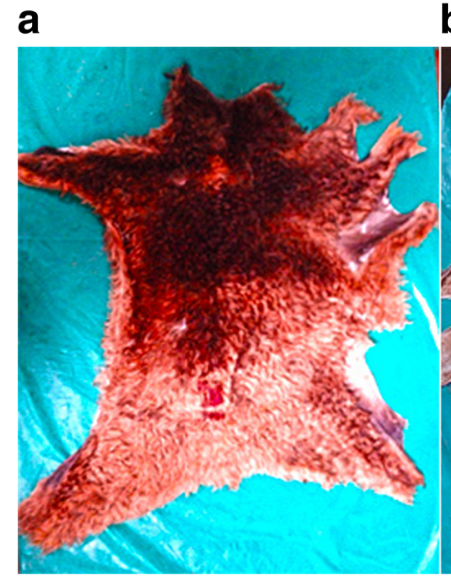

b

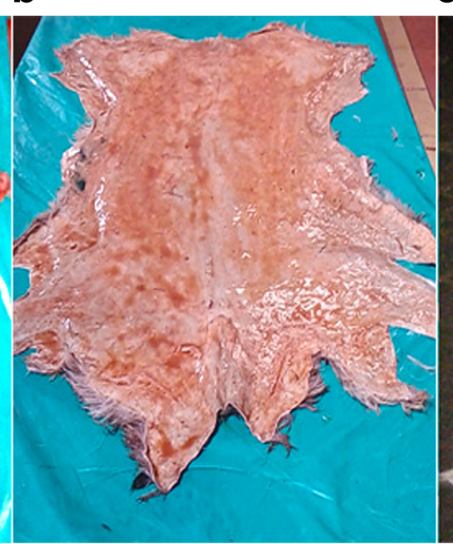

C

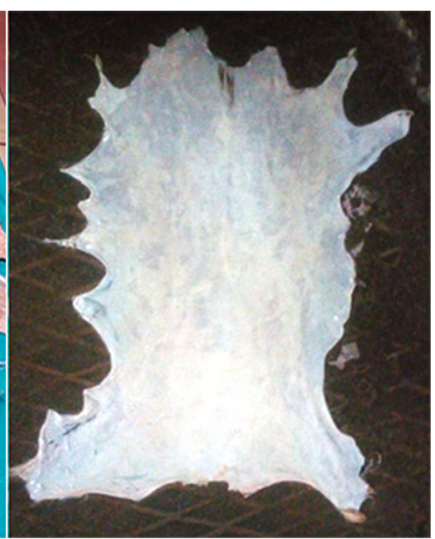

was carried at $\mathrm{pH}$ 9.0. The $\mathrm{pH}$ of the soaked skins was brought up to 9.0 by using $0.15 \%$ magnesium oxide during soaking. The enzyme was mixed with water and was applied uniformly on the flesh layer of the sheepskins and then piled flesh to flesh (Fig. 3b). A set of seven trials was conducted varying the enzyme offer levels and the hide-float ratio (in this case, it refers to the amount of water added), and its effect on unhairing efficacy was studied as presented in Table 8 . Trial 1 resulted in incomplete hair removal, and with trial 2, the hair removal efficacy improved confirming that the enzyme offer level was not sufficient in trial 1. With trial 2, it was observed that short hairs were left on the backbone region and on the corners of the skin. In trial 3, trial 4, trial 5 , and trial 6 , the onset of loosening of hair follicle was observed after $3 \mathrm{~h}$ of application with the enzyme offer greater than 5\%. It was found that $5 \%$ of the enzyme solution was capable of unhairing the sheepskin completely after $6 \mathrm{~h}$ of application. With an increase in enzyme offer level in trial 4, there was no decrease in the overall unhairing duration confirming that an

Table 8 Standardization of concentrated enzyme-based pasting unhairing process parameters — sheepskins

\begin{tabular}{|c|c|c|c|c|c|}
\hline \multirow{2}{*}{$\begin{array}{l}\text { Process } \\
\text { parameter }\end{array}$} & \multirow{2}{*}{$\begin{array}{l}\text { Variation of } \\
\text { process } \\
\text { parameter }\end{array}$} & \multicolumn{3}{|c|}{ Process conditions } & \multirow{2}{*}{$\begin{array}{l}\text { Experiment } \\
\text { legend }\end{array}$} \\
\hline & & $\begin{array}{l}\text { Enzyme } \\
\text { offer } \\
(\% w / w)\end{array}$ & $\begin{array}{l}\text { Hide- } \\
\text { float } \\
\text { ratio } \\
(\% w / w)\end{array}$ & $\mathrm{pH}$ & \\
\hline \multirow{4}{*}{$\begin{array}{l}\text { Enzyme offer } \\
\qquad(\% w / w)\end{array}$} & 1 & - & 10 & 9.0 & Trial 1 \\
\hline & 3 & - & 10 & 9.0 & Trial 2 \\
\hline & 5 & - & 10 & 9.0 & Trial 3 \\
\hline & 7 & - & 10 & 9.0 & Trial 4 \\
\hline \multirow{3}{*}{$\begin{array}{l}\text { Hide-float } \\
\text { ratio (\% } \\
w / w)\end{array}$} & 5 & 5 & - & 9.0 & Trial 5 \\
\hline & 10 & 5 & - & 9.0 & $\begin{array}{c}\text { Trial } 6 \text { (trial } \\
3 \text { ) }\end{array}$ \\
\hline & 15 & 5 & - & 9.0 & Trial 7 \\
\hline
\end{tabular}

enzyme offer of $5 \%$ and a minimum duration of $6 \mathrm{~h}$ are required for complete unhairing of skins.

With a decrease in the hide-float ratio from 10 to $5 \%$ in trial 5 , the amount of enzyme required to spread to form a uniform layer over the flesh side was low leading to the incomplete removal of hair at the areas where enzymes are not sufficient to completely penetrate and do the unhairing. But with trial 7 , the enzyme was higher in quantity leading to running off from the flesh side. Also, the increased dilution of enzymes affected the efficacy of the unhairing process in a negative manner.

Thus, the pasting method of unhairing sheepskin was standardized as $5 \%$ enzyme offer with $10 \%$ hide-float ratio along with $0.25 \% \mathrm{w} / \mathrm{w}$ wetting agent and $0.25 \% \mathrm{w} / \mathrm{w}$ preservative. The preservative was added whenever the skins were left overnight in enzyme pasting method to arrest the putrefaction process by skin-degrading microorganisms. Wetting agent

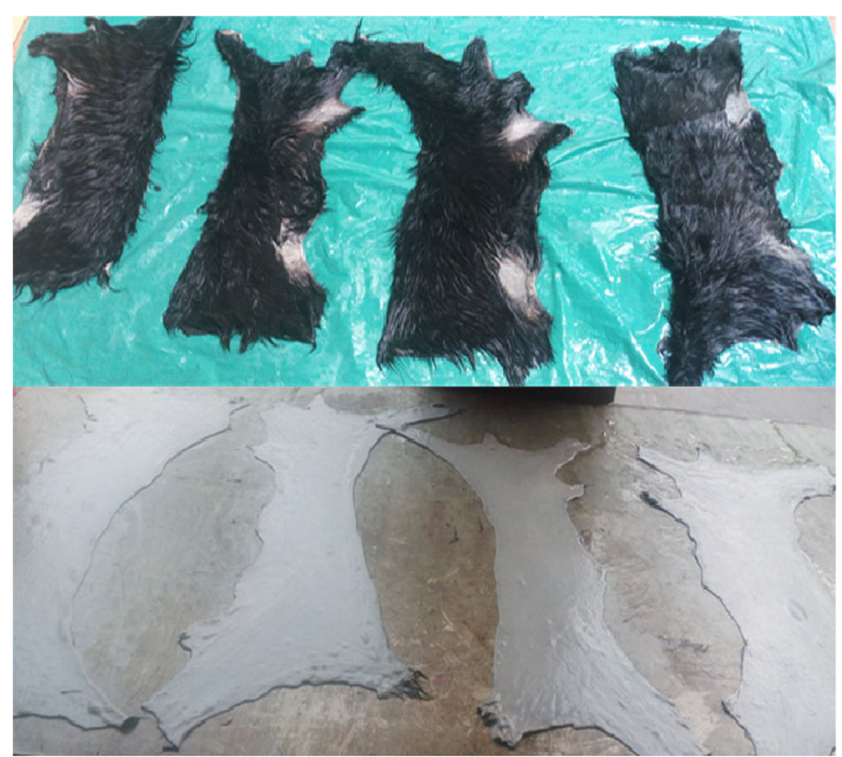

Fig. 4 Soaked goat skins (above) and drum-based SSF enzyme unhaired goat skins (below) (using fermented bran) 
a

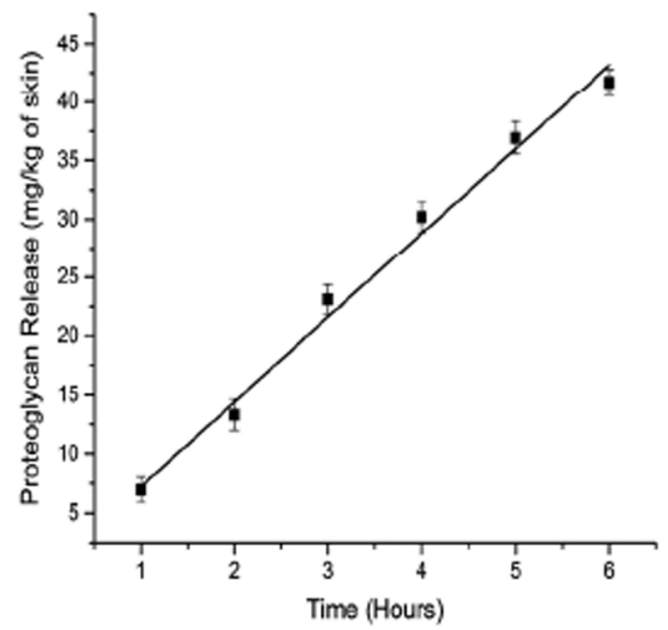

C

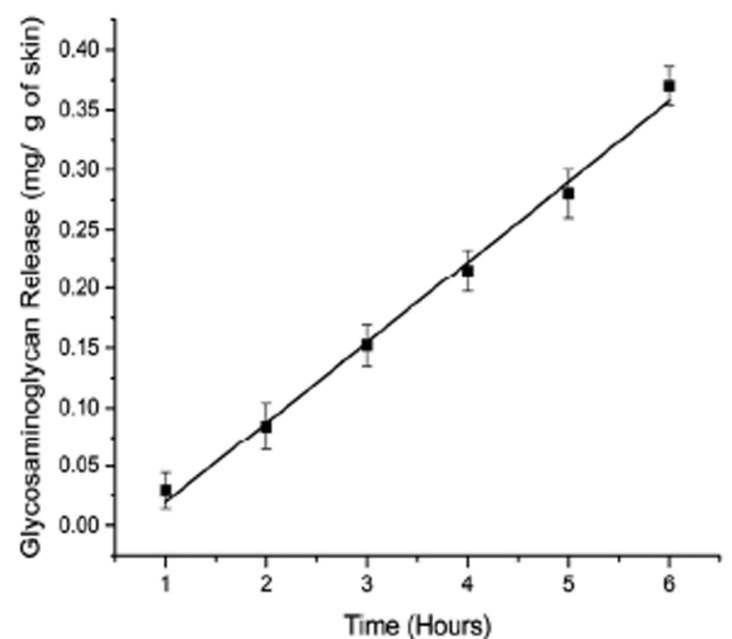

b

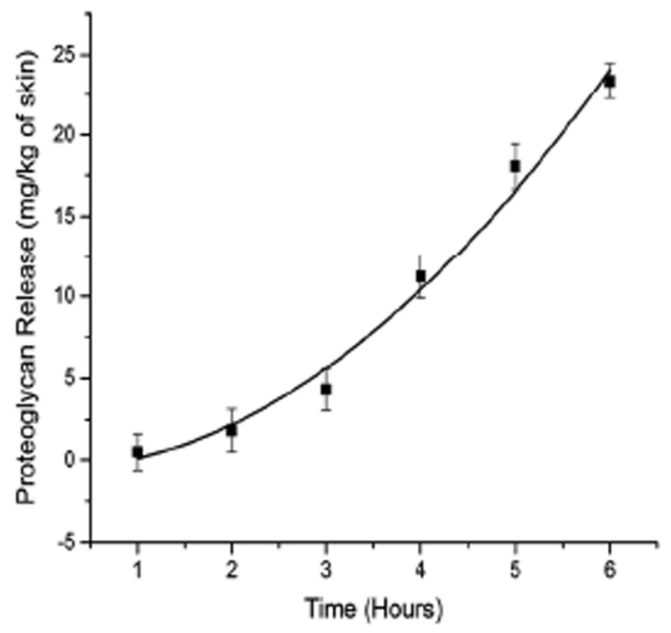

d

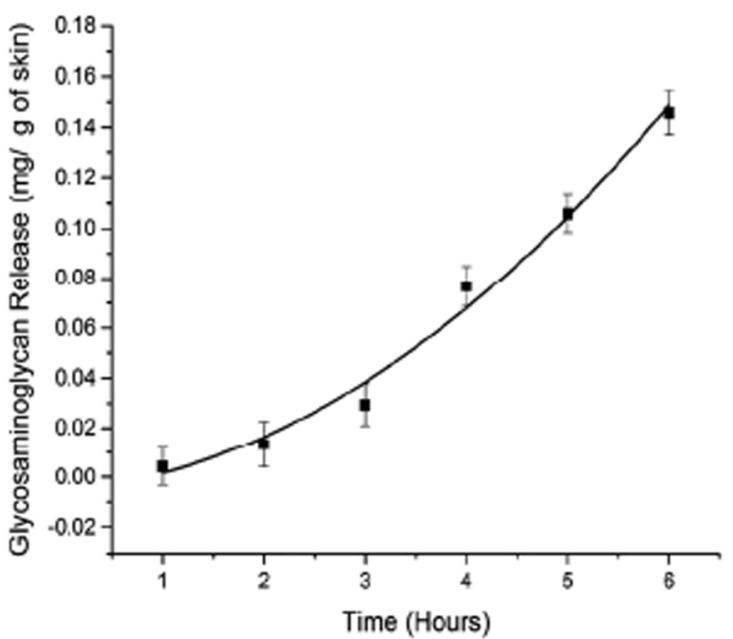

Fig. 5 a PG release profile during drum-based concentrated liquid enzyme unhairing. b PG release profile during SSF enzyme-based unhairing. c GAG release profile during drum-based concentrated liquid enzyme unhairing. d GAG release profile during SSF enzyme-based unhairing

was added to reduce the contact angle between the skin surface and the enzyme droplets to ease the penetration of enzymes into the skin matrix. The unhairing was done after $6 \mathrm{~h}$ of enzyme application manually using a blunt knife and further processing was carried out (Fig. 3c). The same exact process recipe suited for unhairing goatskins, too. This showed that the protease produced was capable of unhairing the animal skins efficiently.

\section{Unhairing of goatskins using SSF fermented bran}

The produced SSF enzyme was assayed for its unhairing efficacy by performing application trials on goatskins. SSF enzyme of $25 \% \mathrm{w} / \mathrm{w}$ (shade-dried fermented bran) was used for the drum-based unhairing of goatskins along with $40 \% \mathrm{w} / \mathrm{w}$ water at an rpm of $5 \pm 1$ (method previously standardized by Renganath et al. 2017). It was found that the loosening of hair was observed after $4 \mathrm{~h}$ of unhairing process and the complete removal of hair was observed after $7 \mathrm{~h}$ of unhairing process (Fig. 4). All $w / w$ calculations were based on the weight of the soaked goatskin.

\section{Internalization of fleshing wastes for the benefit of the leather industry}

Leather processing involves many mechanical operations being done to the raw materials during the course of leather making. The majority of the operations that are done prior to tanning leads to the generation of solid wastes rich in organic components. Fleshing is one such operation that contributes to the generation of almost one third volume of total solid wastes. When $1000 \mathrm{~kg}$ of wet salted rawhide is processed, approximately $300 \mathrm{~kg}$ of fleshing wastes is generated (Buljan et al. 2000). Keeping such huge volume of fleshing wastes in consideration, the feasibility for internalizing this waste for the production of 
Table 9 Pollution load generated by different unhairing methods

\begin{tabular}{|c|c|c|c|c|c|}
\hline \multirow[t]{2}{*}{ Process } & \multicolumn{2}{|c|}{ Pollution load } & \multirow[t]{2}{*}{$\begin{array}{l}\mathrm{BOD}_{5} / \\
\mathrm{COD} \\
(\mathrm{kg} / \mathrm{t})\end{array}$} & \multicolumn{2}{|c|}{$\begin{array}{l}\text { Pollution } \\
\text { reduction in } \\
\text { comparison } \\
\text { to } \\
\text { conventional } \\
\text { method }\end{array}$} \\
\hline & $\begin{array}{l}\mathrm{COD} \\
(\mathrm{kg} / \mathrm{t})\end{array}$ & $\begin{array}{l}\mathrm{BOD}_{5} \\
(\mathrm{~kg} / \mathrm{t})\end{array}$ & & $\begin{array}{l}\text { COD } \\
(\%)\end{array}$ & $\begin{array}{l}\text { BOD } \\
(\%)\end{array}$ \\
\hline $\begin{array}{l}\text { Concentrated liquid enzyme } \\
\text { (drum) and reliming }\end{array}$ & $\begin{array}{l}32.8 \\
\quad \pm 1- \\
.5\end{array}$ & $\begin{array}{l}18.6 \\
\quad \pm 2.3\end{array}$ & 0.57 & 65.8 & 43.0 \\
\hline $\begin{array}{l}\text { Concentrated liquid enzyme } \\
\text { (pasting) and reliming }\end{array}$ & $\begin{array}{l}21.5 \\
\quad \pm 1- \\
.3\end{array}$ & $\begin{array}{r}11.86 \\
\quad \pm 1.9\end{array}$ & 0.55 & 77.6 & 63.7 \\
\hline SSF (drum) and reliming & $\begin{array}{l}19.6 \\
\pm 1- \\
.3\end{array}$ & $\begin{array}{l}10.53 \\
\quad \pm 2.4\end{array}$ & 0.54 & 79.6 & 67.7 \\
\hline $\begin{array}{l}\text { Commercial enzyme* }+ \\
\text { sulfide and reliming }\end{array}$ & $\begin{array}{l}48.2 \\
\quad \pm 1- \\
.4\end{array}$ & $\begin{array}{l}21.54 \\
\quad \pm 2.1\end{array}$ & 0.45 & 49.8 & 34.0 \\
\hline Sulfide paint and reliming & $\begin{array}{l}39.4 \\
\quad \pm 1- \\
.5\end{array}$ & $\begin{array}{l}12.36 \\
\quad \pm 2.0\end{array}$ & 0.31 & 59.0 & 62.1 \\
\hline $\begin{array}{l}\text { Hair burn (conventional } \\
\text { method lime sulfide-based } \\
\text { drum unhairing) }\end{array}$ & $\begin{array}{l}96 \\
\quad \pm 1- \\
.2\end{array}$ & $\begin{array}{l}32.64 \\
\quad \pm 2.4\end{array}$ & 0.34 & 0.0 & 0.0 \\
\hline
\end{tabular}

*Commercial unhairing enzyme from M/s Tex Biosciences (P) Ltd.

FHP followed by unhairing enzyme production can be elaborated. From the previously calculated data in Table 4, it was realized that $20 \mathrm{~kg}$ of fleshing wastes was required for the production of $1 \mathrm{~kg}$ of FHP. Thus, a total of $15 \mathrm{~kg}$ of FHP can be produced using the $300 \mathrm{~kg}$ fleshing waste obtained by processing $1 \mathrm{t}$ of wet salted rawhides. As per Table 2, by employing $1 \mathrm{~kg}$ of FHP $(6 \%$ $w / w$ based on the weight of bran taken for enzyme production) along with $17 \mathrm{~kg}$ of bran, a total of $18 \mathrm{~kg}$ of protease enzyme can be produced through SSF. With this calculation, it can be arrived that the $15 \mathrm{~kg}$ of FHP can result in production of $270 \mathrm{~kg}$ of unhairing protease enzyme. For complete unhairing of sheepskins, an optimized enzyme offer of $25 \% \mathrm{w} / \mathrm{w}$ was required as explained in the subsection "Unhairing of goatskins using SSF fermented bran." For instance, when $1000 \mathrm{~kg}$ of raw sheepskins is to be processed, the required $250 \mathrm{~kg}$ of the unhairing enzyme can be produced from the $300 \mathrm{~kg}$ of fleshing wastes that are being generated. This helps in achieving a $100 \%$ internalization of the fleshing waste produced from the leather industries. Therefore, the internalization of fleshing wastes with such strategy will prove to be a sustainable and eco-friendly route for the valorization of solid wastes.

\section{Kinetics of the drum-based enzymatic unhairing process}

During unhairing, it is reported that the protease degrades the PG and GAG present in the hair bulb and responsible for holding the hair intact with skin. Therefore, the release of PG and GAG is a measure of action of unhairing enzyme on the animal skin (Sivasubramaniam et al. 2008). The PG (mucins and mucoids) concentration of skins is reported to be $0.16-0.2 \%$ of total weight of the skin (McLaughlin and Theis 1925). The carbohydrate (GAG) composition of these PGs (mucin) may account for up to $90 \%$ of its weight (Vilar and Hill 1999). All the PG and GAG release monitoring experiments were conducted in triplicates, and the average values of all three experiments were used for plotting the graph. Sheepskins were used for conducting this study. For drum-based liquid enzyme unhairing, $10 \%$ concentrated enzyme along with $30 \%$ water at an rpm of 5 was followed as the standard unhairing protocol. The release of PG and GAG into the process liquor was monitored every $60 \mathrm{~min}$ during the enzymatic unhairing process. It was noted that the PG loss was linearly increasing following a trend of $Y=7.2346 X(Y=$ PG $\mathrm{mg} / \mathrm{kg}$ of skin; $X=$ time in hours) with an $R^{2}$ value of 0.99096 (Fig. 5a) while using the concentrated liquid enzyme. But in the case of SSF enzyme (fermented bran)based unhairing, the PG release was minimal and it was only significant after $3 \mathrm{~h}$. It followed a polynomial trend of $Y=0.6668 X^{2}+0.1935 X-0.9048(Y=\mathrm{PG} \mathrm{mg} / \mathrm{kg}$ of skin; $X=$ time in hours) with an $R^{2}$ value of 0.98776 (Fig. $5 b)$. This is attributed to the process of leaching out of enzymes from bran, which is then transported into the skin. The PG release was around $41 \mathrm{mg} / \mathrm{kg}$ of skin and $23 \mathrm{mg} / \mathrm{kg}$ of skin while using concentrated liquid enzyme and SSF enzyme after $6 \mathrm{~h}$. Also, the GAG release followed a similar pattern with respect to their proteoglycan release profile. In case of concentrated liquid enzymebased unhairing, the GAG release followed a linear trend of $Y=0.0673 X-0.0471(Y=\mathrm{GAG} \mathrm{mg} / \mathrm{g}$ of skin; $X=$ time in hours) with an $R^{2}$ value of 0.99499 (Fig. 5c), and in the case of SSF enzyme, it followed a polynomial trend of $Y=0.0037 X^{2}+0.0035 X-0.0059(Y=\mathrm{GAG} \mathrm{mg} / \mathrm{g}$ of skin; $X=$ time in hours) with an $R^{2}$ value of 0.9883 (Fig. $5 \mathrm{~d})$. The GAG release was found to be around $0.36 \mathrm{mg} / \mathrm{g}$ of skin and $0.14 \mathrm{mg} / \mathrm{g}$ of skin while using concentrated liquid enzyme and SSF enzyme after $6 \mathrm{~h}$. It was found that GAG release profile was very similar to PG release profile in both the experiments, which proved that the GAG release during enzymatic unhairing was mainly due to the destruction of protein part of the PG.

Thus, the above result corroborates the fact that only the core protein of the PG is broken down leading to the release of glycosaminoglycan in intact form. This confirms that there is no specific interaction of the enzyme with the 


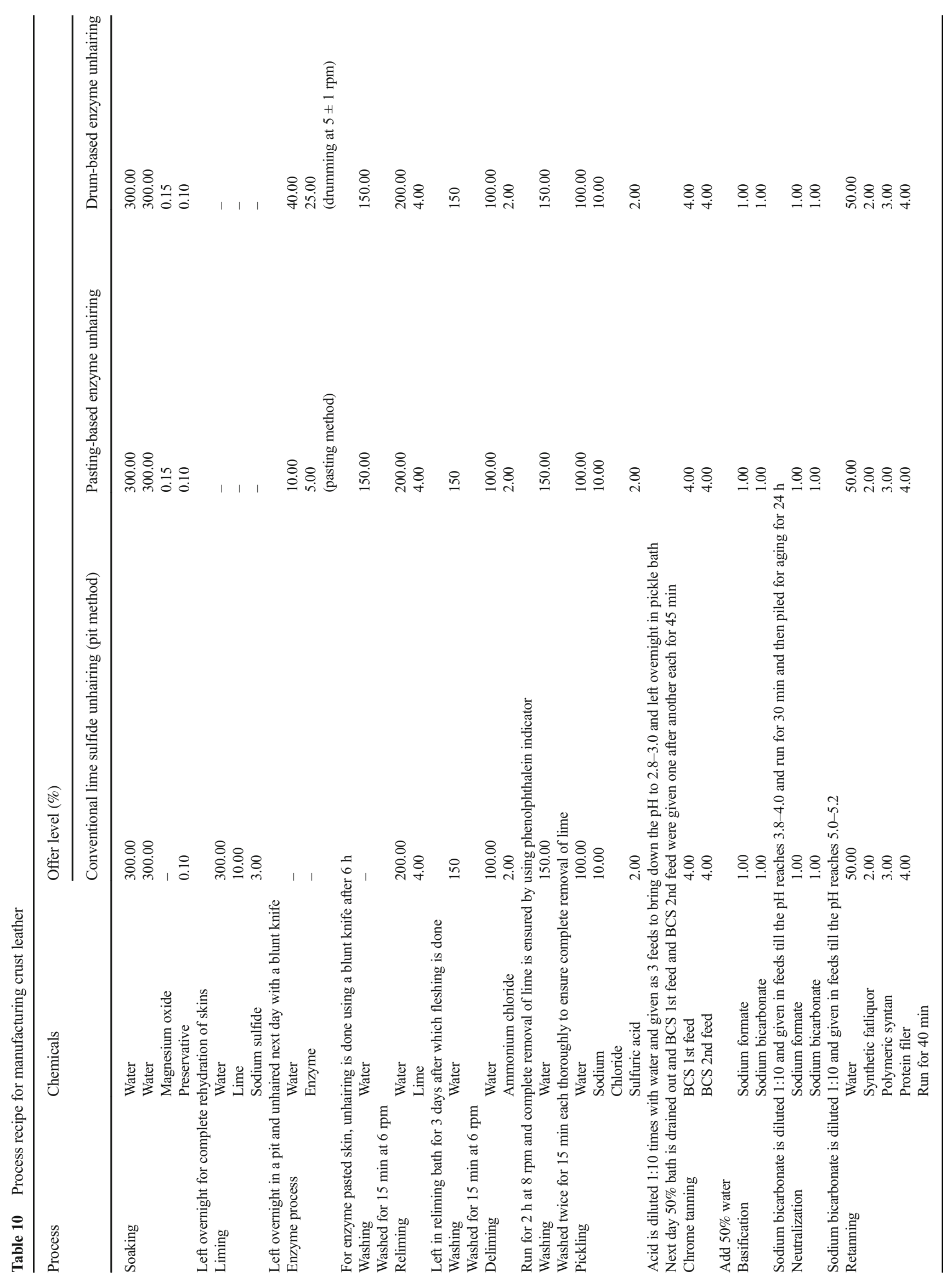




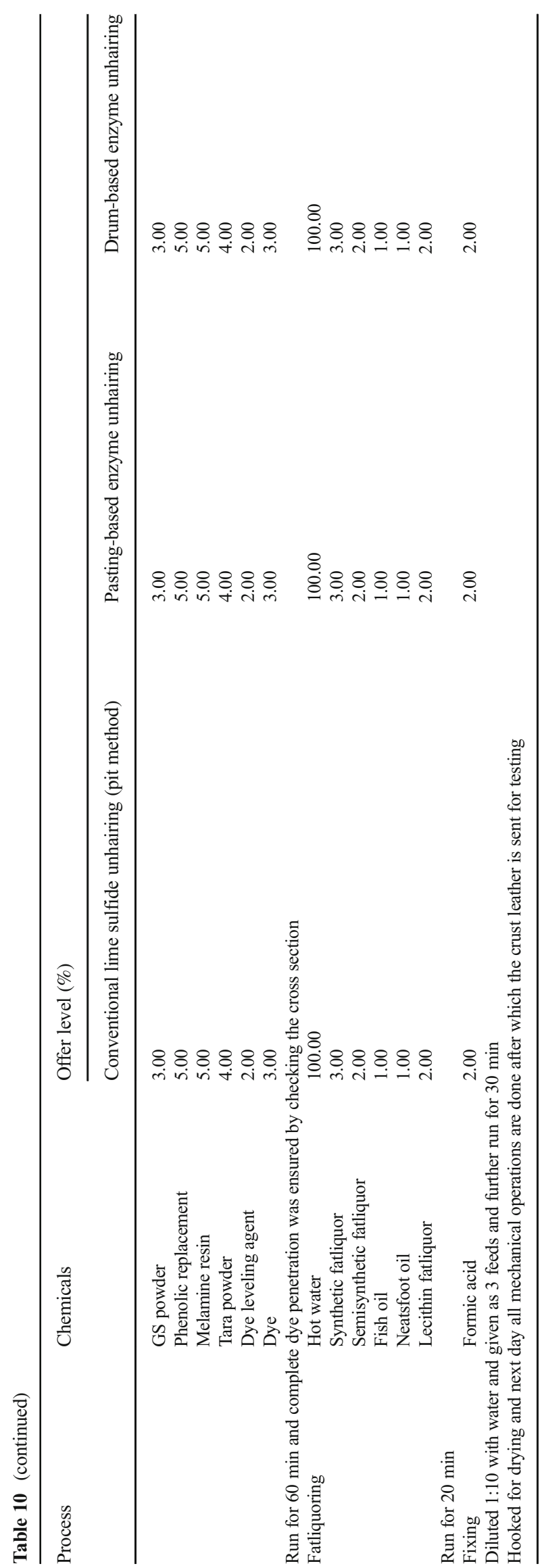

GAG part of the PG. Also, it was found that with an increase in PG loss, there was much damage on the grain surface of the animal skins. Hydroxyproline present in the unhairing process spent liquor was determined to check whether there was any degradation of collagen leading to grain damage. The hydroxyproline content was found to be $480 \pm 12 \mu \mathrm{g}$ that correspond to $0.0358 \mathrm{~g}$ from the spent liquor of $100 \mathrm{~g}$ of enzymatically unhaired skin. The removal of collagen was found to be $0.0358 \%$ (based on the weight of the skin). Thus, a total amount of $0.358 \mathrm{~g}$ of collagen was released per kilogram of skin, which is much lesser than $0.2-0.4 \mathrm{~g}$ collagen destroyed per $\mathrm{kg}$ of skin during strong traditional liming, as reported by Valeika et al. (1997). The initial collagen content of the skin was found to be $30 \%$ based on the total weight of the skin (i.e., $30 \mathrm{~g}$ in $100 \mathrm{~g}$ of skin) and the total loss of collagen after enzymatic unhairing in the spent liquor was around $0.12 \%$ (based on the weight of collagen present initially in the skin; considering $30 \mathrm{~g}$ collagen as 100\%). Such loss in collagen level was also reported when skins were dehaired using bacterial alkaline protease (Sivasubramaniam et al. 2008). From these results, it was confirmed that the problem of grain damage was caused only due to the excessive loss of PG and not the collagen. Thus, the usage of SSF bran directly for unhairing process helped in a lesser loss in PG accompanied by complete hair removal.

\section{Analysis of spent liquor from different unhairing methods}

The waste streams from different unhairing processes were collected and assessed for the pollution parameters such as COD and BOD. The ratio of BOD to COD is a direct indicator for the biodegradability of the wastewater. If the $\mathrm{BOD}_{5} /$ COD is more than 0.5 , then the wastewater is easily biodegradable. Therefore, the effect of the processes on the environment is estimated with these pollution characteristics. The $\mathrm{BOD}_{5} / \mathrm{COD}$ ratio of enzyme-based unhairing processes (both pasting and drum method) showed that the wastewater streams were easily biodegradable as compared to that of the conventional liming method. The COD and BOD values of the conventional liming method (paint liming and hair burn) and the sulfide-assisted commercial enzyme unhairing were found to be high. The paint liming method and the sulfideassisted enzymatic unhairing method are described in the supplementary material (Table S1). The high BOD and COD values in sulfide-assisted commercial enzyme unhairing were due to the destruction of hair by the action of sulfide, but in the case of lime sulfide painting method, only the hair root is destroyed. Therefore, the BOD and COD are lower than the sulfide-assisted enzymatic unhairing process. On the other hand, the higher values of BOD from the 
Table 11 Properties of garment leather made after enzymatic and conventional unhairing method

\begin{tabular}{|c|c|c|c|c|}
\hline Property & $\begin{array}{l}\text { Result } \\
\text { Conventional lime } \\
\text { sulfide unhairing } \\
\text { method }\end{array}$ & $\begin{array}{c}\text { Pasting-based } \\
\text { enzymatic } \\
\text { unhairing }\end{array}$ & $\begin{array}{l}\text { Drum-based SSF } \\
\text { enzymatic } \\
\text { unhairing }\end{array}$ & $\begin{array}{l}\text { Recommended values } \\
\text { as per UNIDO } \\
\text { norms }\end{array}$ \\
\hline \multicolumn{5}{|c|}{ Tensile strength, $\mathrm{N} / \mathrm{mm}^{2}$} \\
\hline Along & $20.4 \pm 1.1$ & $23.6 \pm 0.8$ & $21.4 \pm 1.0$ & \multirow[t]{2}{*}{$\operatorname{Min} 15.0$} \\
\hline Across & $17.0 \pm 0.9$ & $19.0 \pm 0.7$ & $15.6 \pm 1.1$ & \\
\hline \multicolumn{5}{|c|}{ Elongation at break, $\%$} \\
\hline Along & $46.7 \pm 4.3$ & $45.3 \pm 4.0$ & $41.7 \pm 4.1$ & \multirow[t]{2}{*}{$\operatorname{Min} 40.0$} \\
\hline Across & $53.6 \pm 4.9$ & $49.8 \pm 4.7$ & $49.7 \pm 4.6$ & \\
\hline \multicolumn{5}{|c|}{ Tear strength, N/mm } \\
\hline Along & $46.7 \pm 2.3$ & $50.2 \pm 1.9$ & $48.6 \pm 2.1$ & \multirow[t]{2}{*}{ Min 40.0} \\
\hline Across & $40.7 \pm 1.5$ & $45.9 \pm 2.0$ & $41.1 \pm 2.5$ & \\
\hline \multicolumn{5}{|l|}{ Lastometer } \\
\hline $\begin{array}{l}\text { Load at grain } \\
\text { crack, } \mathrm{kg}\end{array}$ & $26.0 \pm 0.8$ & $32.8 \pm 1.2$ & $30.3 \pm 1.1$ & $\operatorname{Min} 20.0$ \\
\hline $\begin{array}{l}\text { Distension at } \\
\text { grain crack, } \\
\mathrm{mm}\end{array}$ & $9.99 \pm 0.3$ & $13.0 \pm 0.2$ & $11.0 \pm 0.3$ & Min 7.0 \\
\hline
\end{tabular}

concentrated liquid enzyme-based drum unhairing wastewater were attributed to the higher amount of release of PG and GAG. But in the case of SSF-based drum unhairing method, the regulated release of enzyme from the bran decreased the excess PG and GAG loss from skin reducing the BOD value of the spent liquor (Table 9). Even though the biodegradability of concentrated liquid enzyme-based drum unhairing process liquor was better, it is advisable not to follow, as the grain damage was inevitable. This further corroborates with the results of PG release as seen in the previous section. The maximum COD and BOD reduction were found to be 79.6 and $67.7 \%$, respectively, for SSF enzyme-based drum unhairing when compared to the conventional hair burn method.

\section{Physical testing of the crust leather}

The effect of enzymatic unhairing method on the final quality of the leather is determined by testing the crust leather for various physical properties. The full process recipe for converting the hide or skins into garment leather through enzymatic unhairing as well as conventional lime sulfide unhairing method is given in Table 10. For these trials, sheepskins were used as the common raw material for conventional lime sulfide method, enzyme pasting method, and SSF drum unhairing process to compare the results obtained from each process.

The garment leather produced by both the conventional method of lime sulfide unhairing system and enzymatic unhairing system was tested for various properties such as tear strength, tensile strength, grain crack, and elongation at break determined by standard procedures (Table 11). It was found that the properties of the crust leathers from enzymatically unhaired sheepskins were on par with the conventional leather manufacturing process. This proved that the enzymatic unhairing as in both paste form and in drum method could completely replace the conventional lime sulfide unhairing system without affecting the quality of the final leather manufactured.

\section{Advantages of using FHP from fleshing waste for SSF enzyme production and its application for unhairing process}

The significant benefits of using FHP from fleshing waste were as follows:

- Optimal usage of solid waste generated from the leather industry eventually reducing the impact of the untreated solid waste on the ecosystem.

- Total internalization of the solid waste generated was made possible which makes this method a sustainable one.

- Elimination of cost involved in downstream processing during enzyme production as the fermented bran was directly used for the unhairing application.

- The residual solid waste after the unhairing process, i.e., the solid bran can be used as fuel for boilers in the leather industry itself.

- Elimination of hazards of chemicals like lime and sodium sulfide, which are used in the conventional unhairing system, by replacing them with the protease-based enzymatic unhairing system.

- Reduction of the cost involved in treating the unhairing process liquor, as the enzymatic unhairing process liquors 
were easily treatable than the conventional unhairing process liquor.

- Minimization of lime sludge formation, which was another major solid waste, produced from the conventional unhairing system.

\section{Conclusions}

FHP obtained by thermal hydrolysis of animal fleshing wastes from the leather industry was found to be a better carbon and nitrogen source for the production of protease along with wheat bran under the SSF process. Thermal hydrolysis of fleshing wastes for $3 \mathrm{~h}$ resulted in $90 \%$ of hydrolysis. An optimized concentration $6 \% w / w$ of FHP in the SSF media composition yielded a maximum protease activity of $956 \mathrm{U} /$ g. The production cost of FHP was found to be within acceptable levels as compared to commercially available media components. Unhairing protease produced using FHP was found to be capable of unhairing the sheepskins and goatskins in $7 \mathrm{~h}$. The physical testing of leathers revealed that the quality of the final leathers from FHP-SSF enzyme unhaired batch was found to be on par with that of the conventionally unhaired pelts. The pollution parameters such as BOD and COD of the spent liquors were indicative of the environment-friendly aspect of the process. The leather industry's solid waste had been put to benevolent use and this internalization makes the method to be a sustainable one. Also, the present work had addressed the solid waste management along with pollution reduction from the pretanning process through the biotechnological route.

Funding information The author acknowledges ZERIS (CSC 0103), CSIR-CLRI for providing funds for carrying out this work.

\section{References}

Andrioli E, Petry L, Gutteres M (2014) Environmentally friendly unhairing: enzymatic-oxidative unhairing as an alternative to use of lime and sodium sulfide. Process Saf Environ Prot 93:9-17

APHA 1989 Standard methods for the examination of water and wastewater, American Public Health Association, $17^{\text {th }}$ edition, Washington, DC

Arunachalam C, Saritha K (2009) Protease enzyme an eco-friendly alternative for leather industry. Ind. J Sci Technol 2:29-32

Ashok P, Selvakumar P, Carlos RS, Poonam N (1999) Solid state fermentation for the production of industrial enzymes. Curr Sci 7:149-162

Bajza Z, Vrcek V (2001) Thermal and enzymatic recovering of proteins from untanned leather waste. Waste Manag 21:79-84

Buljan J, Reich G, Ludvik J (2000) Mass balance in leather processing. In: Regional programme for pollution control in the tanning industry in South-East Asia (US/RAS/92/120); a United Nations Industrial Development Organization report

Bureau of Indian Standards (BIS) (2003) Method of Sampling and Test (Physical and Chemical) for Water and Wastewater, Part 15: Total
Residue (Total Solids-Dissolved and Suspended). IS 3025 (Part 15), 1984 (First Revision)

Castiello D, Puccini M, Salvadori M, Vitolo S, (2006) Reutilization of skin fleshing-derived collagen hydrolyzate in the re-tanning dyeing/ fatliquoring phases. IULTCS II Euro Congress Istanbul, 1-16

Chandrasekaran S, Dhar SC (1983) A low cost method for the production of extracellular alkaline proteinase using tapioca starch. J Ferment Technol 61:511-514

Chellapandi P (2010) Production and preliminary characterization of alkaline protease from Aspergillus flavus and Aspergillus terreus. E-J Chem 7:479-482

Colak S, Zengin G, Ozgunay H, Sarykahya H, Sar O, Yuceer L (2005) Utilisation of leather industry pre-fleshing in biodiesel production. J Soc Leather Technol Chem 100:137-141

Cupp-Enyard C (2008) Sigma's non-specific protease activity assaycasein as a substrate. J Vis Exp. https://doi.org/10.3791/899

Dayanandan A, Hilda VRS, Shanmugavel M, Gnanamani A, Suseela Rajakumar G (2013) Enhanced production of Aspergillus tamarii lipase for recovery of fat from tannery fleshings. Br J Microbiol 44:1089-1095

Dettmer A, Cavalheiro JC, Cavalli E, Rossi DM, Gusatti CDS, Zachia Ayub MA, Gutterres M (2012) Optimization of the biotechnological process for hide unhairing in substitution of toxic sulfides. Chem Eng Technol 35:803-810

Farndale RW, Sayers CA, Barrett AJ (1982) A direct spectrophotometric microassay for sulfated glycosaminoglycans in cartilage cultures. Connect Tissue Res 9:247-248

Fathima NN, Rao JR, Nair BU, (2012) Tannery solid waste to treat toxic liquid wastes: a new holistic paradigm. Environ Eng Sci 29: 363372

Frendrup W, (2000) The scope for decreasing pollution load in leather processing. Regional program for pollution reduction in leather industry in South-East Asia, UNIDO manual, page 20

Gehring A (2002) Unhairing with proteolytic enzymes derived from Streptomyces griseus. J Am Leath Chem Assoc 91:406-411

George N, Chauhan PS, Kumar V, Puri N, Gupta N, (2014) Approach to ecofriendly leather: characterization and application of an alkaline protease for chemical free dehairing of skins and hides at pilot scale. J Cle Pro 1-9. https://doi.org/10.1016/j.jclepro.2014.05.046

George S, Raju V, Krishnan MRV, Subramanian TV, Jayaraman K (1995) Production of protease by bacillus amyloliquefaciens in solid state fermentation and its application in the unhairing of hides and skins. Proc Biochem 30:457-462

Gillespie JM (1953) The depilation of sheepskins with enzymes. J Soc Leather Technol Chem 37:344-353

Harish BK, Sneha VM, Kalal KM, Seeta Laxman R (2015) Eco-friendly enzymatic dehairing of skins and hides by $C$. brefeldianus protease. Clean Techn Environ Policy 17:393-405

IUP 12 (International Commission of Chemical Analysis) (2000) Measurement of resistance to grain cracking and the grain crack index. J Soc Leather Technol Chem 84:317-321

IUP 2 (International Commission of Chemical Analysis) (2000) Sampling location for testing of leathers. J Soc Leather Technol Chem 84:317-321

IUP 6 (International Commission of Chemical Analysis) (2000) Measurement of tensile strength and percentage elongation. J Soc Leather Technol Chem 84:317-321

IUP 8 (International Commission of Chemical Analysis) (2000) Measurement of tear load: double edge tear. J Soc Leather Technol Chem 84:327-329

Jini R, Bijinu B, Bhaskaran V, Bhaskar N (2016) Utilization of solid wastes from tanneries as possible protein source for feed applications: acute and sub-acute toxicological studies to assess safety of products prepared from delimed tannery fleshings. Waste Biomass Valor 7:439-446 
Kamini NR, Hemachander C, Mala JGS, Puvanakrishnan R (1999) Microbial enzyme technology as an alternative to conventional chemicals in leather industry. Curr Sci 77:80-86

Kanagaraj J, Panda RC, Senthilvelan T (2016) Green remediation of sulfide in oxidative dehairing of skin and correlation by mathematical model: an eco-friendly approach. Process Saf Environ Prot 100: $36-48$

Lowry OH, Rosebrough NJ, Farr AL, Randall RJ (1951) Protein measurement with the Folin-phenol reagent. J Biol Chem 193:265-275

Mabrouk SS, Hashem AM, El- Shayeb NMA, Ismail AMS, AbdelFattah AF (1999) Optimisation of alkaline protease productivity by Bacillus licheniformis ATCC 21415. Bioresour Technol 69: $155-159$

Mantle M, Allen A (1978) A colorimetric assay for glycoproteins based on the periodic acid/Schiff's stain. Biochem Soc Trans 6:607-609

McLaughlin GD, Theis ER (1925) Tanning as a science. J Chem Educ 2: 255-260

Mitra P, Chakrabartty PK (2005) An extracellular protease with depilation activity from Streptomyces nogalator. J Sci Ind Res 64:978-983

Morera JM, Bartoli E, Gavilanes RM (2016) Hide unhairing: achieving lower pollution loads, decreased wastewater toxicity and solid waste reduction. J Clean Prod 112:3040-3047

Muthulakshmi C, Gomathi D, Kumar DG, Ravikumar G, Kalaiselvi M, Uma C (2011) Production, purification and characterization of protease by Aspergillus flavus under solid state fermentation. Jordan J Biol Sci 4:137-148

Patel RK, Dodia MS, Joshi RH, Singh SP (2006) Production of extracellular halo-alkaline protease from a newly isolated haloalkaliphilic Bacillus sp. isolated from seawater in western India. World J Micro Biotech 22:375-382

Rajkumar R, Jayapriyan KR, Rengasamy R (2011) Production and characterization of a novel protease from Bacillus sp. RRM1 under solid state fermentation. J Microbio Biotech 21:627-636

Ravindran B, Sekaran G (2010) Bacterial composting of animal fleshing generated from tannery industries. Waste Manag 30:2622-2630

Renganath RR, Vimudha M, Kamini NR, Gowthaman MK, Chandrasekaran B, Saravanan P (2017) Alkaline protease production from Brevibacterium luteolum (MTCC 5982) under solid state fermentation and its application for sulfide-free unhairing of cowhides. Appl Biochem Biotech 182:511-528

Rohm O, (1910) Dehairing and cleaning of skins, German Patent 268.837

Santos LM, Gutterres M (2007) Reusing of a hide waste for leather fatliquoring. J Clean Prod 15:12-16

Saranya R, Prasanna R, Jayapriya J, Aravindhan R, Tamil Selvi A (2016) Value addition of fish waste in the leather industry for dehairing. $\mathrm{J}$ Clean Prod 118:179-186
Saravanabhavan S, Aravindhan R, Thanikaivelan P, Raghava Rao J, Nair BU, Ramasami T (2005) A source reduction approach: integrated bio-based tanning methods and the role of enzymes in dehairing and fibre opening. Clean Techn Environ Policy 7:3-14

Saravanan P, Shiny Renitha T, Gowthaman MK, Kamini NR (2014) Understanding the chemical free enzyme based cleaner unhairing process in leather manufacturing. J Clean Prod 79:258-264

Scroggie JG (1969) A comparative assessment of leather produced by chlorine dioxide and lime sulfide unhairing. J Am Leather Chem Assoc 64:628-642

Shakilanishi S, Chandra Babu NK, Shanthi C (2017) Exploration of chrome shaving hydrolysate as substrate for production of dehairing protease by Bacillus cereus VITSN04 for use in cleaner leather production. J Clean Prod 149:797-804

Sivasubramaniam S, Murali Manohar B, Puvanakrishnan R (2008) Mechanism of enzymatic dehairing of skins using a bacterial alkaline protease. Chemosphere 70:1025-1034

Tengerdy RP (1998) Advances in biotechnology (ed. Pandey A.) Educational Publishers and Distributors, New Delhi, 13-16

Thanikaivelan P, Rao JR, Nair BU (2000) Development of a leather processing method in narrow $\mathrm{pH}$ profile: part 1 . Standardisation of the dehairing process. J Soc Leather Technol Chem 84:276-284

Thanikaivelan P, Rao JR, Nair BU, Ramasami T, (2005) Recent trends in leather making: processes, problems and pathways. Crit Rev Environ Sci Technol 35: 37-39

United Nations Industrial Development Organization (UNIDO) (1996) Acceptable Quality Standards in the Leather and Footwear Industry.]

Valeika V, Balciunieme J, Beleska K, Skrodenis A, Valeikiene V (1997) Use of $\mathrm{NaOH}$ for unhairing hides and the influence of the addition of salts on the process and on the hide properties. J Soc Leather Technol Chem 81:65-69

Valeika V, Beleska K, Valeikiene V, Kolodzeiskis V (2009) An approach to cleaner production: from hair burning to hair saving using a limefree unhairing system. J Clean Prod 17:214-221

Vasudevan N, Ravindran AD (2007) Biotechnological process for the treatment of fleshing from tannery industries for methane generation. Curr Sci 93:1492-1494

Vilar JP, Hill RL (1999) The structure and assembly of secreted mucins. J Biol Chem 274:31751-31754

Woessner JF (1961) The determination of hydroxyproline in tissue and protein samples containing small proportions of this imino acid. Arch Biochem Biophys 93:440-447 